収縮低減剤を塗布したセメントモルタルの乾燥収縮 ${ }^{\dagger}$

\author{
出 村 克 宣* 大 濱 嘉 彦* \\ 森川雅 司** 阿知波政史 ${ }^{* *}$
}

\title{
Drying Shrinkage of Cement Mortars Treated with Shrinkage-Reducing Agents
}

by

\author{
Katsunori Demura*, Yoshihiko OHAmA*, Masashi Morikawa** \\ and Masafumi AchiwA***
}

\begin{abstract}
Cement concrete and mortar have some disadvantages such as low tensile strength, large drying shrinkage and low extensibility. Cracks frequently occur in various concrete structures and mortar walls. In particular, the large drying shrinkage is the most important factor affecting crack formation. Recently, surfactant-type shrinkage-reducing agents for concrete and mortar have been developed in Japan. The shrinkage-reducing agents (SRA) are not only added to fresh concrete and mortar, but also applied on hardened concrete and mortar surfaces. However, the effectiveness of SRA treatments for thin mortar walls in wooden buildings has not been reported till now. The purpose of this study was to make clear the effect of drying shrinkage reduction on the thin mortar by treating with SRA. Mortar specimens with or without SRA were prepared with thicknesses of 10,20 and $40 \mathrm{~mm}$, and covered with an epoxy resin paint except for one side of each specimen. Then four types of SRA were treated at coverage rates of 100 and $300 \mathrm{~g} / \mathrm{m}^{2}$ on the surfaces of the mortar specimens without SRA, and the penetration depth of SRA was measured. The drying shrinkage of the mortar specimens was also measured up to 364 days of dry curing periods. The conclusions obtained from the test results are summarized as follows :

(1) The drying shrinkage of the mortars is considerably reduced by treating with the shrinkage -reducing agents, and depends on the coverage rate of the agents and the thickness of the mortars. The drying shrinkage can be predicted as a function of the coverage rate.

(2) The effectiveness of the shrinkage-reducing agent treatments increases with increasing coverage rate of the agents and with decreasing thickness of the mortars.

(3) On the basis of the above results, the shrinkage-reducing agent treatments are applicable to reduce the drying shrinkage of the finishing mortars troweled on the metal lath bases of wooden buildings.
\end{abstract}

Key words : Drying shrinkage, Shrinkage-reducing agent, Coverage rate, Mortar, Penetration depth, Mortar thickness

\section{1 緒訔}

セメントコンクリートおよびモルタルは, 施工後の 乾燥に伴い収縮し，その伸び能力を越える収縮が生じ た場合には，ひび割れが発生する。これは，鉄筋コン クリート構造物, モルタル壁などの漏水の原因となる ばかりではなく, 外壁の美観を著しく損い, 鉄筋コン クリート構造物の場合には, 水分や気体の透過を容易 にし，鉄筋の腐食を促進させ，鉄筋コンクリート構造 物の耐久性に大きな影響を及ほす。

古くから，セメント系材料の乾燥収縮機構に関して は, 多くの研究が行われており, 今日では, 通常の環
境下におけるその乾燥収縮の主要因は, 包含される水 分の表面張力に起因するという毛細管張力理論が定説 となっている. そのため, 現在, 市販されている界面 活性刻系収縮低減剤の乾燥収縮低減機構は，そのほと んどが, 包含される水分の表面張力を低下させるもの である。一般に, 収縮低減剤は, セメントコンクリー トおよびモルタルの練り混ぜ時に混入されるが, セメ ントコンクリート拉よびモルタルの硬化後にそれを塗 布含浸させた場合でも，その乾燥収縮を低減すること ができるといわれている. 究は, 鉄筋コンクリート構造物の外壁などに生じる乾

\footnotetext{
$\dagger \quad$ 原稿受理 昭和63年11月 2 日 Received Nov. 2, 1988

* 正会 員 日本大学工学部 郡山市田村町, College of Engineering, Nihon University, Tamura-machi, Koriyama

** 学生会員 日本大学大学院 郡山市田村町, Graduate Student, Nihon University, Tamura-machi, Koriyama

$* * *$ 東亞合成化学工業(株)研究所 名古屋市港区船見町, Toagosei Chemical Industry Co., Ltd., Funami-cho, Minato-ku, Nagoya
} 
Table I. Properties of cement.

\begin{tabular}{|c|c|c|c|c|c|c|c|c|c|c|}
\hline \multirow{2}{*}{$\begin{array}{l}\text { Specific } \\
\text { tgravity }\end{array}$} & \multirow{2}{*}{$\begin{array}{l}\text { Blaine's } \\
\text { specific } \\
\text { surface } \\
\text { area } \\
\left(\mathrm{cm}^{2} / \mathrm{g}\right)\end{array}$} & \multicolumn{2}{|c|}{ Setting time } & \multirow{2}{*}{ Soundness } & \multirow{2}{*}{$\begin{array}{c}\mathrm{MgO} \\
(\%)\end{array}$} & \multirow{2}{*}{$\begin{array}{l}\mathrm{SO}_{3} \\
(\%)\end{array}$} & \multirow{2}{*}{$\begin{array}{l}\text { ig. loss } \\
(\%)\end{array}$} & \multicolumn{3}{|c|}{$\begin{array}{l}\text { Compressive strength of mortar } \\
\qquad\left(\mathrm{kgf} / \mathrm{cm}^{2}\right)\end{array}$} \\
\hline & & $\begin{array}{c}\text { Initial set } \\
(\mathrm{h}-\mathrm{min})\end{array}$ & $\begin{array}{l}\text { Final set } \\
(\mathrm{h}-\mathrm{min})\end{array}$ & & & & & $3 d$ & $7 \mathrm{~d}$ & $28 \mathrm{~d}$ \\
\hline 3.16 & 3280 & $2-26$ & $3-31$ & Good & 1.3 & 1.7 & 0.7 & 139 & 242 & 424 \\
\hline
\end{tabular}

燥収縮ひび割れを対象としたものが多く，七メントモ ルタルの代表的な用途の一つである左官工法を対象と したものは，ほとんど見当らないのが現状である.

本研究では, 左官工法, 特に, 下地からの水分の供 給がない，木造建築物におけるラス下地の上に塗装さ れるモルタル壁の施工を想定した． 3 種類の厚さを持 ち，一面のみを残してシールし，シールしていない面 に各種収縮低減剤を塗布したモルタルおよび, 収縮低 減剤を混入した同様のモルタルについて, 乾燥材令 1 年までの乾燥収縮を測定する．その結果より，モル夕 ルの乾燥収縮に及ぼす収縮低減剤の塗布量およびモル タルの厚さの影響並びに収縮低減剂の混入効果につい て検討すると共に，モルタルの乾燥収縮低減策として の収縮低減剤塗布工法の有効性について検討している.

\section{2 使用 材 料}

\section{$2 \cdot 1$ セメントおよび骨材}

セメントには，普通ポルトランドセメントを，骨材 には，豊浦標準砂を使用した。 セメントの性質を Table I に示す.

\section{$2 \cdot 2$ 収縮低減剂}

収縮低減剤（SRA）には, 低級アルコールアルキ レオンオキシド付加物系（SRA-1），グリコールエー テル系（SRA-2)，ポリオキシエチレンポリオキシプ ロピレンモノアルキルエーテル系（SRA-3）および ポリプロピレングリコール系（SRA-4）の 4 種類の 市販品を用いた。 収縮低減剤の性質を Table II に示 す.

\section{$3 \cdot 1$ 供試体の作製}

\section{3 試 験 方 法}

セメント:豊浦標準砂 $=1: 3$ (重量比) とした調合 の供試モルタルを，そのフロー値が $170 \pm 5$ 一定とな るように練り混ぜ水量を調整し, JIS R 5201 (セメ ントの物理試験方法）に従って練り混ぜ, 調製した。 なお, 比較のため, 収縮低減剤混入率を $2 \mathrm{wt} \%$ （セ

Table II. Properties of shrinkage-reducing agents.

\begin{tabular}{c|c|c|c}
\hline $\begin{array}{c}\text { Type of } \\
\text { SRA }\end{array}$ & $\begin{array}{c}\text { Specific } \\
\text { gravity } \\
\left(20^{\circ} \mathrm{C}\right)\end{array}$ & $\begin{array}{c}\mathrm{pH}\left(20^{\circ} \mathrm{C}\right) \\
{\left[\begin{array}{l}\% \text { aqueous } \\
\text { solution }\end{array}\right]}\end{array}$ & $\begin{array}{c}\text { Viscosity } \\
\left(20^{\circ} \mathrm{C}, \mathrm{cP}\right)\end{array}$ \\
\hline SRA-1 & 1.00 & 6.0 & 20 \\
\hline SRA-2 & 1.04 & 6.8 & 55 \\
\hline SRA-3 & 0.99 & 6.0 & 15 \\
\hline SRA-4 & 1.02 & 7.0 & 100 \\
\hline
\end{tabular}

Table III. Mix proportions of base mortars and mortars containing SRA.

\begin{tabular}{|c|c|c|c|c|c|}
\hline $\begin{array}{l}\text { Type of } \\
\text { mortar }\end{array}$ & $\begin{array}{c}\text { Cement : } \\
\text { Sand (by } \\
\text { weight) }\end{array}$ & $\begin{array}{l}\text { SRA } \\
\text { content } \\
(\%)\end{array}$ & $\begin{array}{l}\text { Water- } \\
\text { cement } \\
\text { ratio } \\
(\%)\end{array}$ & $\begin{array}{c}\text { Air } \\
\text { content } \\
(\%)\end{array}$ & Flow \\
\hline $\begin{array}{l}\text { Untreated and } \\
\text { uncontaining } \\
\text { mortar }\end{array}$ & \multirow{5}{*}{$1: 3$} & 0 & 80.0 & 6.1 & 171 \\
\hline $\begin{array}{l}\text { Containing } \\
\text { SRA-1 }\end{array}$ & & \multirow{4}{*}{2.0} & 75.0 & 9.4 & 171 \\
\hline $\begin{array}{l}\text { Containing } \\
\text { SRA-2 }\end{array}$ & & & 76.0 & 6.1 & 168 \\
\hline $\begin{array}{l}\text { Containing } \\
\text { SRA-3 }\end{array}$ & & & 75.0 & 9.3 & 167 \\
\hline $\begin{array}{l}\text { Containing } \\
\text { SRA-4 }\end{array}$ & & & 75.0 & 7.5 & 168 \\
\hline
\end{tabular}

メントに対する）とした調合の供試モルタルも同様に 調製した。供試モルタルの調合を Table III に示す.

調製したモルタルを，厚さを 10,20 および $40 \mathrm{~mm}$ に変化させ, 寸法 $40 \times 160 \times 10 \mathrm{~mm}, 40 \times 160 \times 20$ $\mathrm{mm}$ および $40 \times 160 \times 40 \mathrm{~mm}$ の板状に成形した後， 1 日湿空 $\left(20^{\circ} \mathrm{C}, 80 \%\right.$ R.H. $)$ 養生して脱型した。なお, 成形時に, 乾燥収縮測定のために，モルタルの寸法 $40 \times 160 \mathrm{~mm}$ の一側面に乳白ガラスを埋込んだ. 脱型 後，モルタルの乳白ガラス埋込み面に，はけを用いて， 塗布量 0,100 および $300 \mathrm{~g} / \mathrm{m}^{2}$ で各種収縮低減剤を 塗布し, 他の面については, エポキシ樹脂塗料でシー ルして, 材令 3 日まで湿空養生を継続し, 供試体とし た.

\section{$3 \cdot 2$ 収縮低減剂の浸透深さの測定}

各種収縮低減剂塗布直後の寸法 $40 \times 160 \times 40 \mathrm{~mm}$ の 供試体を二分割し, その断面を自然乾燥させ, ぬれ色 を呈する部分を収縮低減剤の浸透域として, 供試体表 面からの深さを測定した.

\section{$3 \cdot 3$ 乾燥収縮試験}

JIS A 1129 (モルタルおよびコンクリートの長さ 変化試験方法）のコンパレーター法に従って，3日間 湿空養生後の供試体について基長を測定した．その後， 供試体を $20^{\circ} \mathrm{C}, 50 \%$ R. H. の乾燥条件下に静置し, $7 ， 28 ， 56 ， 91 ， 182$ および 364 日の各乾燥材令にお いて, その乾燥収縮を測定した。

\section{4 試験結果および考察}

Fig. 1 には, 収縮低減剤のモルタルに対する浸透深 さを示す．収縮低減剤のモルタルに対する浸透深さは, 


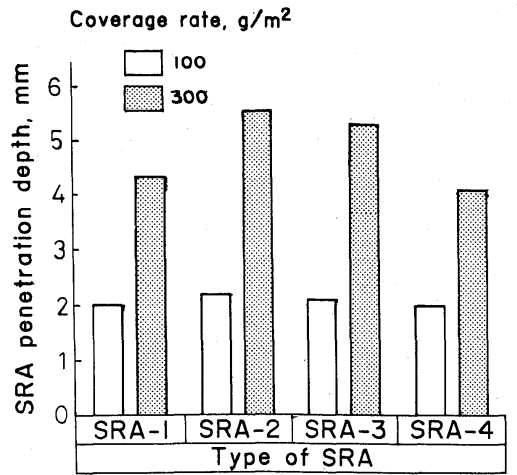

Fig. 1. Penetration depth of shrinkage-reducing agents.

その塗布量によって異なり，塗布量を $100 \mathrm{~g} / \mathrm{m}^{2}$ とし た場合の浸透深さは，2.0 2.3 mm， $300 \mathrm{~g} / \mathrm{m}^{2}$ とした 場合のそれは，4.1～5.4 mmである. 又, 塗布量を一 定とした場合でも，収縮低隇剤の種類によって，モル タルに対する浸透深さは若干異なるようである.

Fig. 2 から Fig. 4 には, 各種収縮低減剂塗布モル夕 ルおよび混入モルタルの乾燥材令と乾燥収縮の関係を 示す。モルタルの厚さにかかわらず，収縮低減剤塗布 モルタルおよび混入モルタルの乾燥収縮は, 乾燥材令 91 日まで増大し，それ以後，一定となる傾向にある。 又, いずれの乾燥材令においても, 収縮低減剤未塗布 （未混入）モルタルに比べて, 収縮低減哃塗布モル夕 ルおよび混入モルタルの乾燥収縮は小さい。収縮低減

Dry curing period, $d$

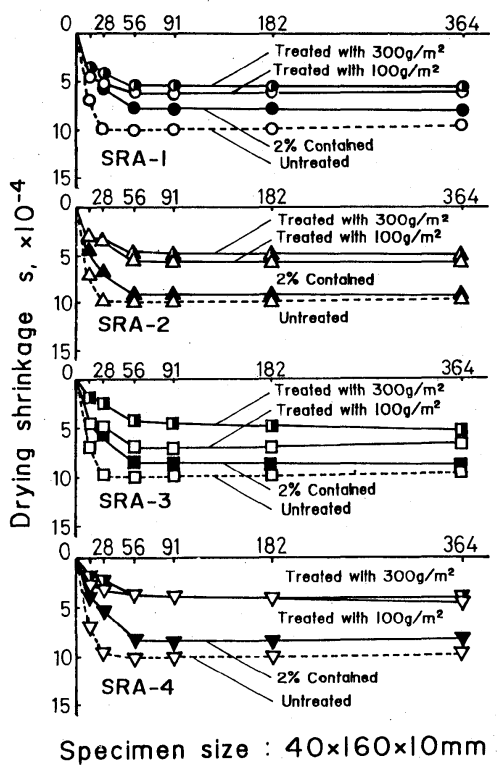

Fig. 2. Dry curing period vs. drying shrinkage of SRA-containing and -treated mortars $(40 \times 160$ $\times 10 \mathrm{~mm}$ ).

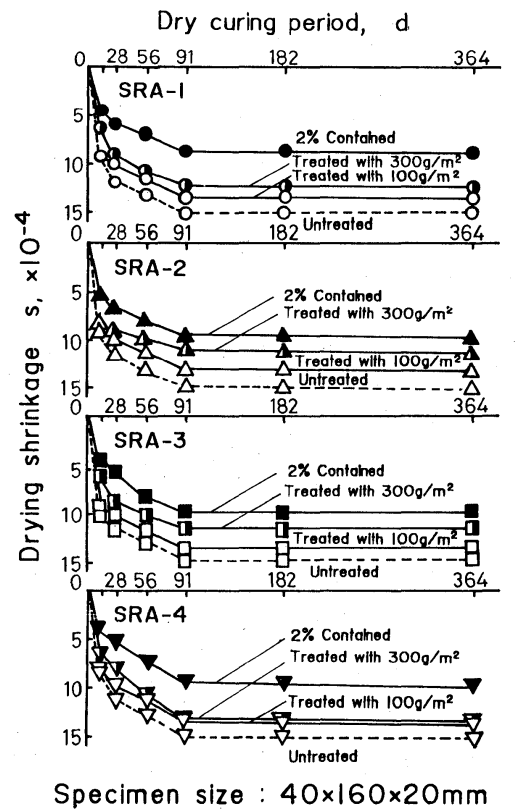

Fig. 3. Dry curing period vs.. drying shrinkage of SRA-containing and -treated mortars $(40 \times 160$ $\times 20 \mathrm{~mm}$ ).

剤の種類にかかわらず，厚さ $10 \mathrm{~mm}$ のモルタルにお いては, 収縮低減剤混入モルタルに比へてて, 収縮低減 剂塗布モルタルの乾燥収縮は小さいが，厚さ 20 およ び $40 \mathrm{~mm}$ のモルタルにおいては, 収縮低減剤混入モ ルタルの乾燥収縮が最も小さい，収縮低減剤の塗布量

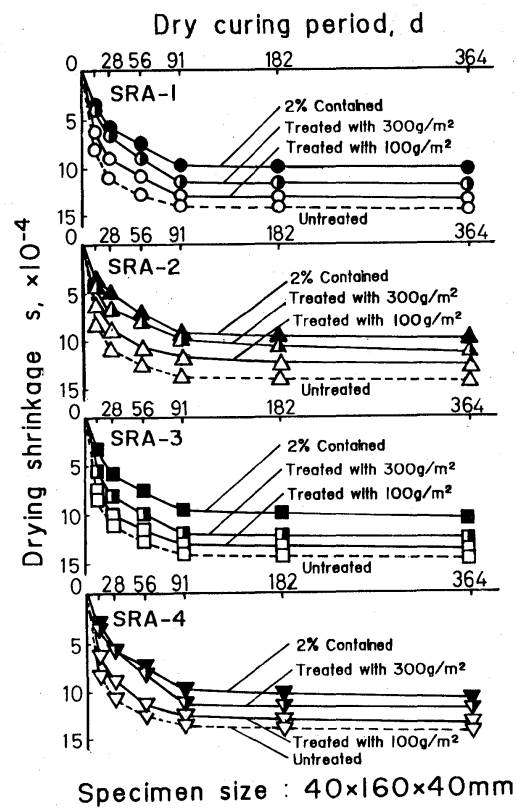

Fig. 4. Dry curing period vs. drying shrinkage of SRA-containing and -treated mortars $(40 \times 160$ $\times 40 \mathrm{~mm}$ ). 
と浸透深さから, 浸透部分の収縮低減剤量を算出する と, 塗布量を 100 および $300 \mathrm{~kg} / \mathrm{m}^{2}$ とした場合, そ れぞれ，約 10 および $15 \mathrm{wt} \%$ （セメントに対する） となる。したがって, これは, 収縮低減剤の混入量に 比べれば相当に大きな值であり, 収縮低減剂の浸透深 さが小さいものにもかかわらず，厚さ $10 \mathrm{~mm}$ のモル タルにおいては, この差が顕著に現れ, 収縮低減剤混 入モルタルに比べて, 収縮低減剤塗布モルタルの乾燥 収縮が小さくなるものと考える。 しかし，厚さ 20 お よび $40 \mathrm{~mm}$ のモルルにおいては, 収縮低減剤未浸 透部分の収縮の影響によって，収縮低減剤混入モル夕 ルに比べて, 収縮低減剤塗布モルタルの乾燥収縮は大 きくなるものと推察される. 一方, 収縮低減剤の種類 およびモルタルの厚さにかかわらず, 収縮低減剤塗布 量の増大に伴い, 収縮低減剤塗布モル夕ルの乾燥収縮 は, 小さくなる傾向にある. そこで, 収縮低減剤の塗 布量と乾燥材令 364 日における収縮低減剤塗布モル夕 ルの乾燥収縮の関係を図示したものが，Fig. 5 から Fig. 8 である.これらの図から明らかなように, 収縮

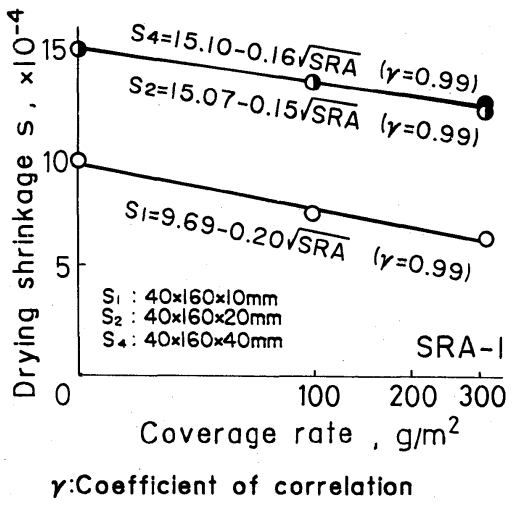

Fig. 5. Coverage rate $v$ s. drying shrinkage of mortars treated with shrinkage-reducing agent (SRA-1)

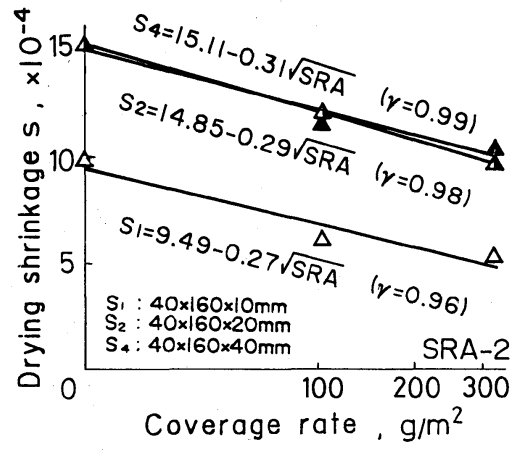

$r$ :Coefficient of correlation

Fig. 6. Coverage rate vs. drying shirinkage of mortars treated with shrinkage-reducing agent (SRA-2).

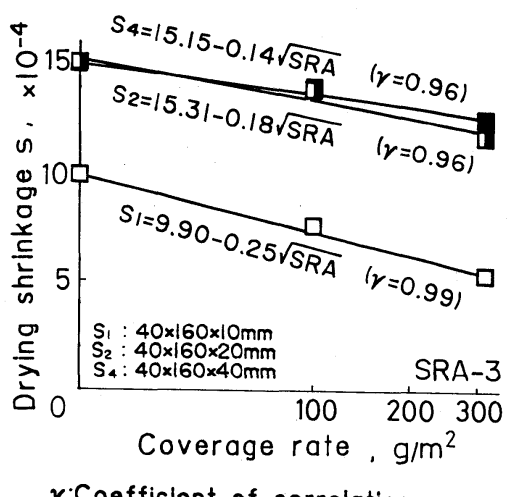

$r$ :Coefficlent of correlation

Fig. 7. Coverage rate $v s$. drying shrinkage of mortars treated with shrinkage-reducing agent (SRA-3)

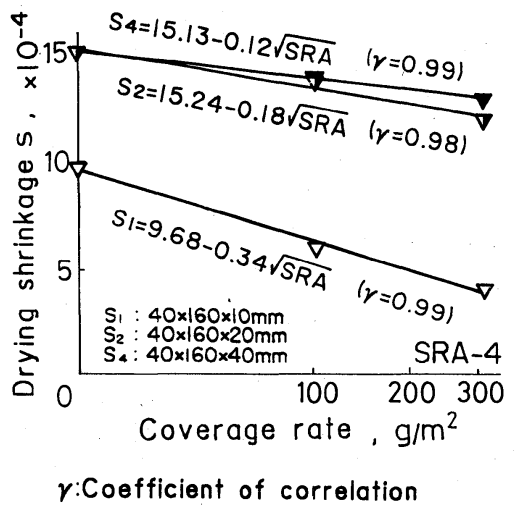

Fig. 8. Coverage rate vs. drying shrinkage of mortars treated with shrinkage-reducing agent (SRA-4).

低減剂塗布モルタルの乾燥収縮は，収縮低減剂塗布量 の平方根と負の相関が認められ，その関係は，次のよ うな実験式で表される.

$$
\mathrm{S}=\mathrm{A}-\mathrm{B} \sqrt{\mathrm{SRA}}
$$

ここに, $\mathrm{S}$ : 収縮低減剤塗布モルタルの乾燥収縮 $\left(\times 10^{-4}\right)$

$\mathrm{SRA}$ : 収縮低減剤の塗布量 $\left(\mathrm{g} / \mathrm{m}^{2}\right)$

$\mathrm{A}$ および $\mathrm{B}$ : 実験定数

モルタルの厚さが同じであっても，上述の一般式に おける実験定数 $\mathrm{A}$ および $\mathrm{B}$ は収縮低減剤の種類に よって異なることから，モルタルの厚さおよび収縮低 減剤の塗布量を一定とした場合でも，モルタルの乾燥 収縮に及ほすす収縮低減剤の塗布効果は，収縮低減剤の 種類によって異なることが示唆される，なお，収縮低 減剂塗布の有無にかかわらず，厚さ $10 \mathrm{~mm}$ のモル夕 ルに比べて，厚さ 20 および $40 \mathrm{~mm}$ のモルルの乾燥 収縮は大きく, 又, 厚さ 20 および $40 \mathrm{~mm}$ のモルタル の乾燥収縮はほぼ同様の值を与える。この理由につい て, 本研究の限りでは明らかでない.一般に, コンク 
リートでは，乾燥によって，表面から水分が蒸発する と, 内部に水分勾配が生じるため, 不等収縮（表層部 と内部の不均一な収縮）が起こり，これによってコン クリート自体が拘束を受けるといわれている。．本研究 のように，モルタルの一面からのみ水分が蒸発して乾 燥する場合, 表層部で測定される乾燥収縮について考 察すると次の通りである。(1)表層部の乾燥収縮は, 初 期には，その厚さにかかわらず，内部に生じる水分勾 配がほぼ同じであるため，内部の収縮による拘束を同 様に受けるものと推測される. (2)その後の表層部の乾 燥収縮は, 水分の表面までの平均移動距離の増加に 伴って低隇される内部の収縮による拘束と蒸発による 水分損失の相乗効果に大きく依存し，その厚さによる 差異を生じるものと考えられる.(3)この場合, 表層部 の乾燥収縮に対して, モルタルの厚さが $20 \mathrm{~mm}$ まで は, 蒸発による水分損失の効果が大きいが, 厚さが $20 \mathrm{~mm}$ を越えると, 内部の収縮の低減による拘束の 効果が顕著になるものと推察される.

Fig. 9 から Fig. 11 には，次のように定義した乾燥 材令 364 日における収縮低減剤の塗布によるモルタル の乾燥収縮低減率と収縮低減剤塗布量の関係を示す。

$$
\mathrm{R}_{\mathrm{s}}=\frac{\mathrm{S}_{0}-\mathrm{S}_{i}}{\mathrm{~S}_{0}} \times 100
$$

ここに, $\mathrm{R}_{\mathrm{s}}$ : 乾燥収縮低滅率 $(\%)$

$\mathrm{S}_{0}$ ：ある乾燥材令に扮ける収縮低減剤未塗 布モルタルの乾燥収縮 $\left(\times 10^{-4}\right)$

$\mathrm{S}_{i}:$ 収縮低減剤未塗布モルタルと同じ乾燥 材令における収縮低減剤塗布モルタル の乾燥収縮 $\left(\times 10^{-4}\right)$

いずれの収縮低減㘊をモルタルに塗布した場合でも， その塗布量の増加に伴い, モルタルの乾燥収縮低隇率 は大きくなる傾向にある。一方，収縮低減剂の塗布量 にかかわらず，モルタルの乾燥収縮低減率は，その厚 さが薄いものほど大きく, 収縮低減剤の塗布による乾

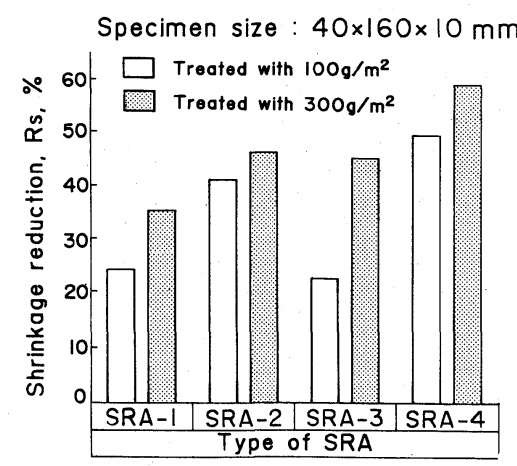

Fig. 9. Coverage rate vs. shrinkage reduction of mortars $(40 \times 160 \times 10 \mathrm{~mm})$ treated with shrinkage-reducing agents.

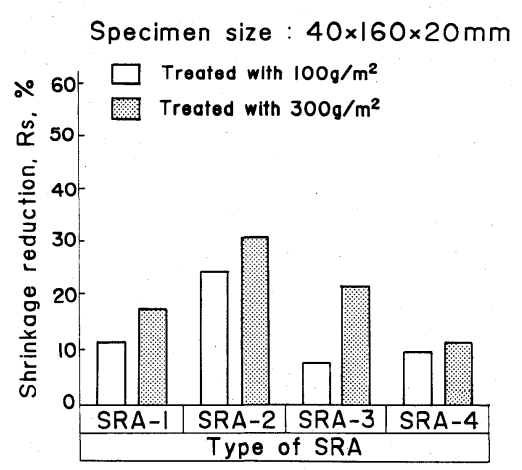

Fig. 10. Coverage rate vs. shrinkage reduction of mortars $(40 \times 160 \times 20 \mathrm{~mm})$ treated with shrinkage-reducing agents.

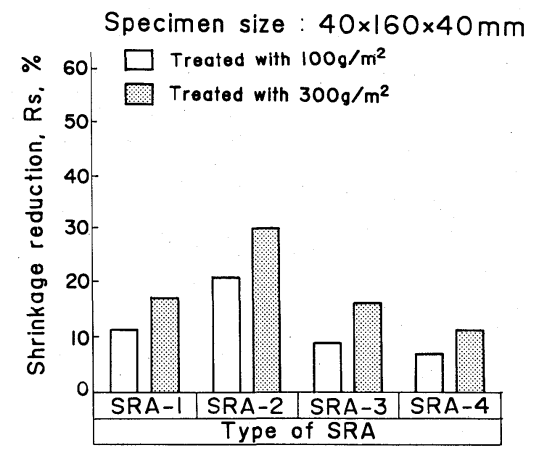

Fig. 11. Coverage rate vs. shrinkage reduction of mortars $(40 \times 160 \times 40 \mathrm{~mm})$ treated with shrinkage-reducing agents.

燥収縮低減の効果は, モルタルの厚さが薄いものほど 顕著である. 又, モルタルの厚さが薄いものほど, 収 縮低減剤の種類による収縮低減効果の差が顕著に現れ るようである. 特に, グリコールエーテル系拉よびポ リプロピレングリコール系の収縮低滅剤は, 薄いモル タルに抏いて優れた乾燥収縮低減効果を与える。なお, モルタルの厚さにかかわらず, 本研究で用いた収縮低 減剂の中では, グリコールエーテル系収縮低減剤が最 も優れた乾燥収縮低減効果を与えるようである.

本研究における試験結果から推察すれば，収縮低減 剤をモルタル壁へ塗布する工法は, その乾燥収縮低減 策として有効であるが，その工法による乾燥収縮低減 効果はモルタルの厚さに依存するといえる.

\section{5 結論}

以上の試験結果を総括すれば，次の通りである.

（1）収縮低減剂のモルタルに対する浸透深さは，そ の塗布量によって異なり, 塗布量を $100 \mathrm{~g} / \mathrm{m}^{2}$ とした 場合の浸透深さは, $2.0 \sim 2.3 \mathrm{~mm}, 300 \mathrm{~g} / \mathrm{m}^{2}$ とした場 合のそれは, $4.1 \sim 5.4 \mathrm{~mm}$ である. 又, 塗布量を一定 とした場合でも, 収縮低減剤の種類によって，モル夕 ルに対する浸透深さは若干異なる。 
（2）いずれの乾燥材令に抢いても，収縮低減剤未塗 布 (未混入) モルタルに比へてて, 収縮低減剂塗布モル タルおよび混入モルタルの乾燥収縮は小さい. しかし, 収縮低減剤の種類にかかわらず，厚さが $10 \mathrm{~mm}$ の場 合, 収縮低減剂混入モルタルに比べて, 収縮低減剤塗 布モルタルの乾燥収縮は小さく，厚さが 20 および 40 $\mathrm{mm}$ の場合には，収縮低減剤混入モルタルの乾燥収縮 が最も小さい.

（3）収縮低減剤の種類抢よびモルタルの厚さにかか わらず，収縮低減剂塗布量の増大に伴い，収縮低減剂 塗布モルタルの乾燥収縮は小さくなる傾向にある。そ の場合, 収縮低隇剤塗布モルタルの乾燥収縮は, 収縮 低減剤塗布量の平方根と負の相関が認められ，式(1)の ような実験式で表される，この式を用いて，収縮低減 剤塗布モルタルの乾燥収縮を算定することができる。

（4）収縮低減剤の塗布量にかかわらず，収縮低減剤 塗布による乾燥収縮低減効果は，モルタルの厚さが薄 いものほど顕著である. 特に, グリコールエーテル系 およびポリプロピレングリコール系の収縮低減剤は, 薄いモルタルにおいて優れた乾燥収縮低減効果を与え る.

（5）以上の結果によれば，木造建築物の外壁などに
おいて, メタルラス下地のような水分の供給がない下 地の上に塗装する仕上げモルタルに，収縮低減剤を塗 布する工法は，その乾燥収縮低減策として有効である と推察される.

（昭和62年 日本材料学会第 36 期学術譜演会, 昭和63年 日本材料学会第37期学術講演会にて講演)

\section{参 考 文 献}

1) R. H. Smith and R. H. Mills, "Variations in the Shrinkage of Concrete Resulting from the Use of Additives", Proceedings of the RILEM/CEMBUREAU International Colloquium on the Shrinkage of Hydraulic Concretes, V. 1, Instituto Eduardo Torroja, Madrid, 1968, pp. II-G. 0-II-G. 15.

2 ) 富田六郎，城所卓明，“含浸法による収縮低減剤の利用”, 第 6 回コンクリート工学年次講演会論文集, May 1984, pp. 361-364.

3 ) 富田六郎, 山下善秀, 井上 潔, “乾燥収縮低減剤を含 浸させたコンクリートの性状について”, pp. 387-390, セメント技術年報40（1986）.

4) Neville, A. M., "Properties of Concrete" (3rd Edition) pp. 384-387 (1981) Pitman, London. 